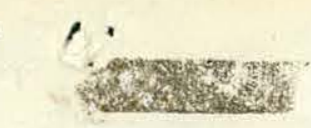

THE JACKSON LABORATORY

Bar Harbor, Maine 04609

3 November 1980

\title{
MASTER
}

Progress Report to accompany

Fourteenth renewal proposal to the

Division of Biomedical and and Environmental Research

Department of Energy

Washington, DC 20545

Contract number:

Title of project:

Investigator:

Period of report:
EV-76-S-02-3267

\section{IMPROVED MUTAGEN-TESTING SYSTEMS IN MICE}

Thomas H. Roderick, Ph.D.

Senior Staff Scientist

Principal Investigator

1 September 1979 to 30 October 1980

\section{NOTICE}

This report was prepared as an account of work sponsored by the United States Government. Neither the United States nor the United States Department of Energy, nor any of their employees, nor any of their contractors, subcontractors, or their employees, makes any warranty, express or implied, or assumes any legal liability or responsibility for the accuracy, completeness, or usefulness of any information, apparatus, product or process disclosed, or represents that its use would not infringe privately owned rights.

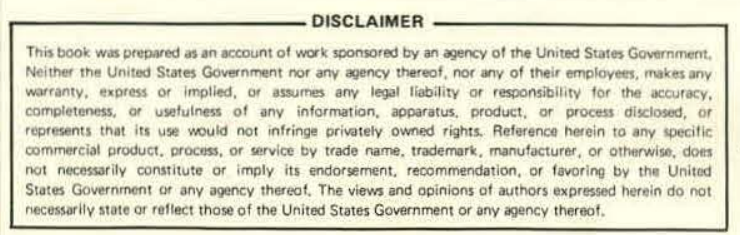

there is no objection from the parea poiat of viaw to the pubitcetion or dissespination of the documsat(s) itatiad is wis better.

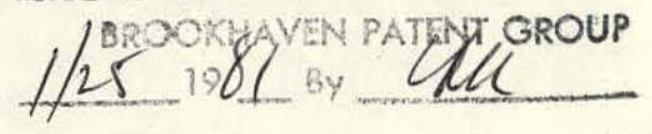




\section{DISCLAIMER}

This report was prepared as an account of work sponsored by an agency of the United States Government. Neither the United States Government nor any agency Thereof, nor any of their employees, makes any warranty, express or implied, or assumes any legal liability or responsibility for the accuracy, completeness, or usefulness of any information, apparatus, product, or process disclosed, or represents that its use would not infringe privately owned rights. Reference herein to any specific commercial product, process, or service by trade name, trademark, manufacturer, or otherwise does not necessarily constitute or imply its endorsement, recommendation, or favoring by the United States Government or any agency thereof. The views and opinions of authors expressed herein do not necessarily state or reflect those of the United States Government or any agency thereof. 


\section{DISCLAIMER}

Portions of this document may be illegible in electronic image products. Images are produced from the best available original document. 


\section{UNCLASSIFIED}

Distribution

7 - Senior Procurement Official

Department of Energy-Headquarters

Washington, DC 20545

1 - Assistant Director

Budget and Fiscal

The Jackson Laboratory

5 - Principal Investigator

The Jackson Laboratory

1. - Assistant Direstinr

Grants Management

The Jackson Laboratory

14 


\section{OBJECTIVE}

The purpose of this project is to produce improved mutagen-testing systems in mice. Our approach is to produce chromosomal inversion systems and to inprove the techniques necessary to induce, detect, genetically define, and combine inversions in effective useful mutation-test systems. Another specific objective has been to test the systems produced with respect to their effectiveness. Another objective has been to mark, maintain, and study recessive detrimentals and lethals induced in the validation-testing of these systems. of particular importance is to study induced recessives for dominant effects on fitness. A final broad objective has been to use the induced inversions and recessive lethals for studies of basic problems in mammalian genetics, growth and development.

\section{SCOPE OF RESEARCH}

The inversions, Robertsonians, and translocations induced need to be genetically and cytologically mapped precisely so that specific mutation-test systems can be constructed. Then useful combinations of these need to be constructed and then validated in a mutation test assay. In addition to the practical need for mutation-test systems which these aberrations afford, it is important to study the nature and effects of the inversions themselves, especially in meiosis, so that problems in their use can be identified and avoided. At the present time, the idiosyncrasies of mammalian inversions, such as absence of reduced reproductive performance, have added to their value in the objectives of this program.

\section{MAIN RESEARCH ACCOMPLISHMENTS}

Inversions produced. We induce and detect inversions by looking for first meiotic anaphase bridges in one testis of sons of males treated with radiation or a chemical mutagen. The natural frequency of bridges at this division is about 5 per cent, making it necessary to search for animals which display a frequency significantly in excess of 5 per cent. These inversions are all paracentric inversions, since anaphase bridges are not characteristics of pericentric inversions. We also need to induce and study pericentric inversions and thus another method was established to use simultaneously. The chromosomes of the mouse are all acrocentric providing little probability of inducing pericentric inversions, since breaks would need to occur on both sides of the centromere. Therefore we have given triethylene melamine (TEM) as a mutagen to mice carrying at least three Robertsonian chromosomes and examined the banded karyotypes of sons and daughters for presence of pericentric inversions in these chromosomes.

These methods continue to be useful in inducing inversions. Table 1 shows all the inversions and presumptive inversions produced in our laboratory to date. The table shows the different lengths of the inversions (indicated by their characteristic bridge frequency), the various chromosomes affected, and the variety of possible physiological decrements associated with inversions. Inversions this past year have been induced primarily in Robertsonian carrying 
stocks. Our intention was to: (1) place paracentric inversions in both arms of a Robertsonian chromosome with the objective of tying up more of the genome in a single chromosome mutation-test system and (2) increase our chances of inducing a pericentric inversion. The POS lines in which Robertsonian chromosomes occur naturally were imported several years ago. We have recently imported some additional Robertsonian stocks which cover various acrocentric combinations and which permit us to make better decisions on which acrocentric pairs are most suitable for an inversion test-system. Table 2 lists our Robertsonian stocks which give us combinations of 33 different chromosomal pairs.

The 25 useful inversions are spread around the genome rather well. There are inversions now on all chromosomes except Chromosomes 6, 16, 17, 18, and 19. The only inversion on the $X$-chromosome (Chromosome 20) was induced at Harwell, England. We imported this stock and have the inversion in homozygous condition. Except for Chromosome 6, the chromosomes lacking induced inversions are the smallest four. This is not surprising when one considers that induced inversions is probably correlated with the chromosomal target size. We do not see it in our interest to continue to produce inversions until all chromosomes are studied. Rather we not feel it is important to put the greatest effort in validating the inversion system as an indicator of mutations. We are therefore reducing our effort to induce inversions and increasing our work on validation.

The pericentric inversion reported last year has been designated In(11.13LS)29Rk. It involves about 34 per cent of $\mathrm{Rb}(11.13) 4 \mathrm{Bnr}$ as measured. on both Giemsa-banded mitotic chromosomes and synaptonemal complexes. The female in which the inversion was first detected produced three offspring and only transmitted the invereion to onc son. This male was sterile. He carried no other detectable abnormalities. Both light and electron microscope analyses of meiotic preparations indicated delays in the meiotic process with accumulation of early meiotic cells and decreased numbers of later stages and mature sperm. Analysis of synaptonemal complexes also showed synaptic delay and a high frequency of association of the unpaired regions with the $X-Y$ bivalent. Light microscope analysis showed a high frequency of metaphase I cells with early separation of $X-Y$ bivalent. Interference with the $X-Y$ bivalent is being observed by us and others as a common feature of many sterile conditions in the mouse. Paracentric inversions do not produce significant fertility problems and we suspect the first meiotic anaphase bridges resulting from crossing over within the inverted segment may be important in preventing the transmission of unbalanced gametes. Crossing over within a pericentric inversion will not form anaphase bridges because the centromere is within the inversion. Therefore we might expect reduced fertility in a pericentric inversion heterozygote. The observations with In29Rk support this hypothesis.

Combining chromosomal inversions and Robertsonians. We have successfully combined inversion In(1)1Rk and Robertsonian Rb(1.3)1Bnr so that this chromosome has the middle portion of the long arm inverted. The stock is homozygous and breeds well with a litter size of 6 to 9 . The stock is also homozygous for $\mathrm{Rb}(8.12) 5 \mathrm{Bnr}$ and $\mathrm{Rb}(9.14) 6 \mathrm{Bnr}$. This makes it a good stock to use for placing inversions in other Robertsonians to create a stock with multiple inversion-bearing Robertsonian chromosomes. We already have available inversions in $\operatorname{Chr} 3,8,9,12$, and 14 . In(1) 12Rk has also been inserted by recombination into the long arm of $\mathrm{RblBnr}$. The heterozygotes are mated together and we are typing the offspring for homozygotes.

$$
\text { Page } 4
$$


INVERSIONS INLUCED IN THE MOUSE

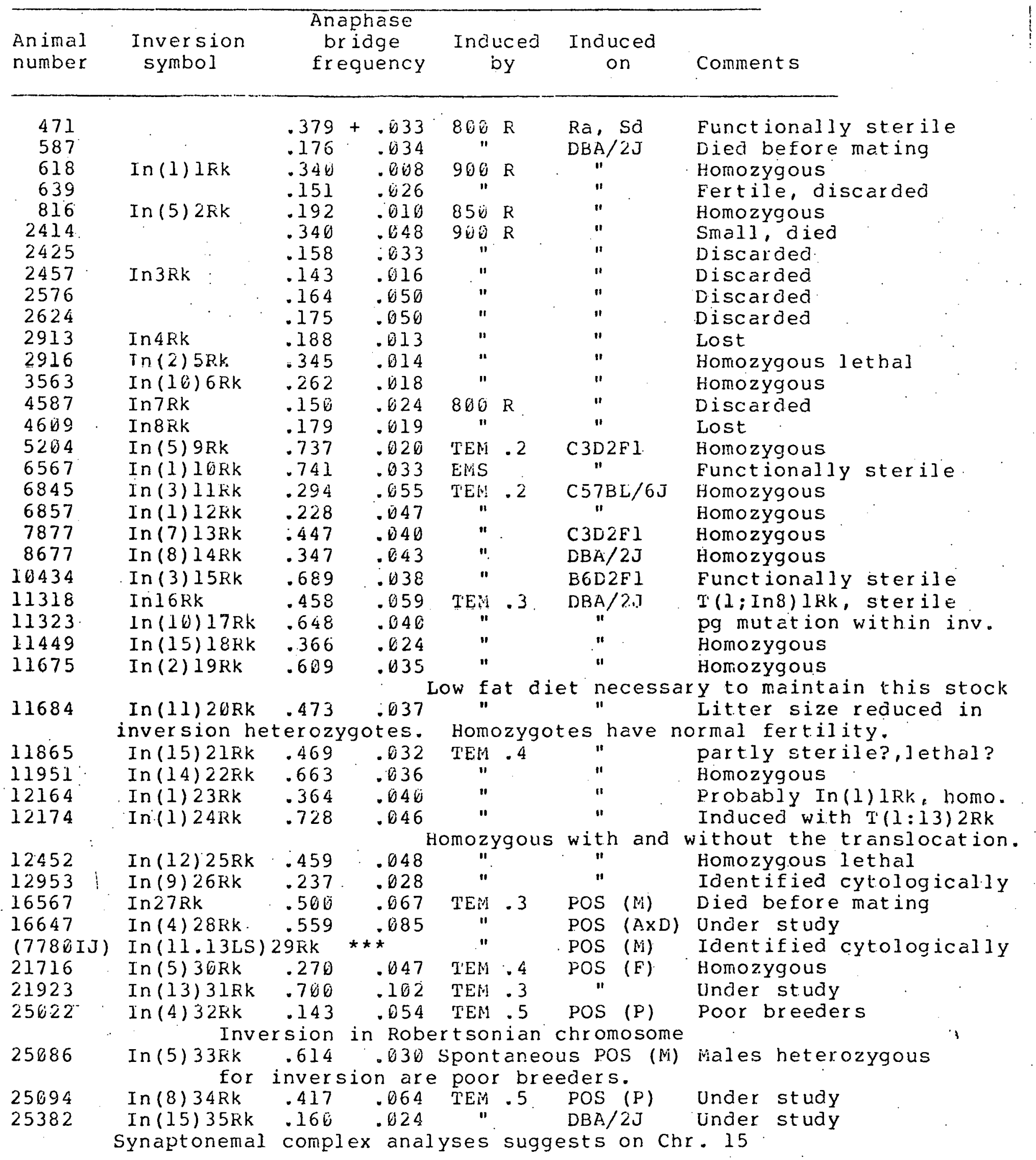

Footnotes, next page 
* Numbers by TEM indicate dosage in $\mathrm{mg} / \mathrm{kg}$ body weight:

* * Symbols represent strains, stocks, or hybrids. pos are stocks carrying Robertsonian chromosomes.

*** Identified first in a female by blood culture and G-banding. A pericentric inversion will not produce anaphase bridges in the first meiotic division.

Inversion symbols:

In refers to inversion.

Number in parenthesis is the chromosome in which the inversion occurs.

Number following parenthesis or alone is the number of the inversion found in our laboratory.

$\mathrm{Rk}$ is the symbol of our laboratory. 
ROBERTSONIAN CHRONOSOMES MAINTAINED IN THR/MTE COLONY - Arm Compo- Homo-

Dèsignaticn $:$ sition cygous comments $8 / 29 / 80$

Laboratory Origin

$\mathrm{kb}(4.15)$ lkk

$\mathrm{Rb}(3.15) 2 \mathrm{Rk}$

$\mathrm{Kb}(6.15) 1 \mathrm{Ald}$

$\mathrm{Kb}(9.19) 163 \mathrm{H}$

$\mathrm{Rb}(8.17) 1$ Iem

Feral origin

$\mathrm{Rb}(1.3)$ I Bnr

$\mathrm{Rb}(4.6) 2 \mathrm{Bnr}$

$\mathrm{Kb}(5.15) 3 \mathrm{Bnr}$

$\mathrm{Rb}(11.13) 4 \mathrm{Bnr}$

$\mathrm{Rb}(8.12) 5 \mathrm{Bnr}$

$\mathrm{Rb}(9.14) 6 \mathrm{Bnr}$

$\mathrm{Rb}(16.17) 7 \mathrm{Bnr}$

$\mathrm{Rb}(4.12) 9 \mathrm{Bnr}$

$\mathrm{Rb}(1.10) 16 \mathrm{Bnr}$

$\mathrm{Kb}(1.7)$ I kma

$\mathrm{Rb}(3.8) 2 \mathrm{Rma}$

$\mathrm{Rb}(4.15) 4 \mathrm{Rma}$

$\mathrm{Rb}(10.11) 5 \mathrm{Rma}$

$\mathrm{Rb}(2.18) 6 \mathrm{Rma}$.

$\mathrm{Rb}(5.17) 7 \mathrm{kma}$

$\mathrm{Rb}(12.14) 8 \mathrm{Rma}$

$\mathrm{Rb}(1.18) 10 \mathrm{kma}$

$\mathrm{Rb}(2.17) 11 \mathrm{kma}$

$\mathrm{Rb}(4.11) 12 \mathrm{Rma}$

$\mathrm{kb}(6.7) 13 \mathrm{Rma}$

$\mathrm{kb}(5.15) 15 \mathrm{kma}$

$\mathrm{Rb}(8.14) 16 \mathrm{Rma}$

$\mathrm{kb}(10.12) 17 \cdot \mathrm{kma}$

$\mathrm{Kb}(1.3)$ l Lub

$\mathrm{Rb}(2.8) 2 \mathrm{Lub}$

$\mathrm{Rb}(4.6) 3 \mathrm{Lub}$

$\mathrm{Kb}(5.15) 4 \mathrm{Lub}$

$\mathrm{Rb}(10.12) 5 \mathrm{Lub}$

$\mathrm{Rb}(11.13) 6 \mathrm{Lub}$

$\mathrm{Rb}(9.14) 7 \mathrm{Lub}$

$\mathrm{Rb}(16.17) 8 \mathrm{Lub}$

$\mathrm{Kb}(7.18) 9 \mathrm{Lub}$

$\mathrm{Rb}(3.9) 12 \mathrm{Lub}$

$\mathrm{Kb}(1.2) 18 \mathrm{Lub}$

$\mathrm{Rb}(5.14) 21 \mathrm{Lub}$

$\mathrm{Rb}(8.12) 22 \mathrm{Lub}$

$\mathrm{Fb}(10.15) 23 \mathrm{Lub}$

$\mathrm{Rb}(6.16) 24 \mathrm{Lub}$
4.15

3.15

6.15

9.19

8.17

1.3

4.6

5.15

11.13

8.12

9.14

16.17

4.12

1.10

1.7

3.8

4.15

10.11

2.18

5.17

12.14

1.18

2.17

4.11

6.7

5.15

8.14

10.12

$\begin{aligned} 1.3 & \text { no } \\ 2.8 & \text { yes } \\ 4.6 & \text { no } \\ 5.15 & \text { no } \\ 10.12 & \text { yes } \\ 11.13 & \text { no } \\ 9.14 & \text { no } \\ 16.17 & \text { no } \\ 7.18 & \text { yes } \\ 3.9 & \text { yes }\end{aligned}$

1.2

5.14

8.12

10.15

6.16 yes

yes

yes

yes

$y \in s$

yes

yes

yes

yes

yes

yes

yes

yes

$y \in s$

yes

yes

yes

yes

yes

yes

no

yes

no

yes

Yes

no

no

no

no

yes

no

yes

no

no

no

yes

no

yes

no

yes

yes
In stock with kbl63H

In stock with R.blalo

Poschiavinus, Swiss Alps
$" 1 "$
$" 1 "$
$" 1 "$
$"$
$" 1 "$

Mutten near Vià liàla

(Upper khine Valley)

* Never crossed to laboratory strain

Val Bregaglia, village of Bondo

CD, Central Italy, Apennine, Abruzzi

"

"

$n$

"

$C B$, Central Italy, Apennine, Mol ise

i"

II

It

It

II

Orobie, Northern Italy, Bergamo

"

"

11

แ)

11

ii

ACR, from central Italy, Anceráno

Lipari, Southern Italy, Isole Eolie

"

"

II 
A stock of mice carrying both $\operatorname{In}(1) 1 R k$ and $\operatorname{In}(7) 13 R k$ has been constructed. This stock used as a assay for mutations is more than double the efficiency of that we have employed using only In(l)IRk. The increased number of animals needed in the test generation to discern the presence of lethals is not a major drawback. We are now using this stock to validate the mutation assay both within the laboratory and in the field. This work is described later in this report.

Cytology of inversions. Considerable effort this year has been spent on identifying the cytological breakpoints of inversions and utilizing cytological methods for determining the chromosomal location of jnversions. The cytological breakpoints for all inversions characterized are listed in Table 3.

We also have continued to improve our culture method for high resolution banding of mouse chromosomes to assist us in mapping breakpoints cytologically. We have determined that mouse blood cells in culture are extremely sensitive to the DNA synthesis inhibitor, methotrexate, which has been used to synchronize cultured human lymphocytes. Our approaches are to try (1) shortening the time of exposure to methotrexate, (2) decreasing the concentration of methotrexate. in the medium, and (3) harvesting cells as close to the first DNA synthetic period as possible to take advantage of the partial synchrony in the first division cycle following culture initiation. In all cases it is simply a matter of finding the proper timing of treatment and harvest of cells.

Translocations. We now maintain several useful reciprocal translocations which we have induced in our inversion screening program. A list of these and their cytologically identified breakpoints is given in Table 4 . We are using them to help locate new inversions and in combination with inversions to study the meiotic effect in a mammal having two different chromosomal aberrations involving the two homologues of the same chromosome. Translocations also generally inhibit genetic recombination in the areas of breakpoints. We have considered the possibility of utilizing some translocations in mutation-test systems but at the present time feel they are less satisfactory than inversions alone or inversions in combination with Robertsonians.

Mutagen test validation. During the past year no new lethals have been induced in the mutation-test system utilizing inversion In(1)1Rk. We believe this is due to the deterioration in activity of our supply of TEM. The problem of determining the activity of the TEM has always plagued us, and we perhaps have as much data as exists anywhere on the deterioration of TEM activity with time. We are now using a cesium source, giving 1000R and mating shortly after treatment to obtain the mutation damage induced in sperm and spermatids. In this work we are utilizing our double-inversion stock containing inversions In(1)1Rk and In(7)13Rk. In this mutation-test system, we use Sp (splotch) and In (leaden) in testing for lethals on Chr 1 and isozyme markers Gpi-1 (glucose phosphate isomerase) and $\mathrm{Hbb}$ (hemoglobin beta chain) for assessing lethals induced in Chr 7.

The double inversion stock is also being used to assess lethal mutations in wild populations. This work is being done in collaboration with Dr. Michael Petras of the University of Windsor, Ontario, Canada. Dr. Petras, a biochemical and population geneticist, spent several weeks in our laboratory a year ago working out biochemical techniques and preparing for the testing of this inversion system on wild populations. Twenty wild mice, 10 females and 10 males, 
TABLE 3 - CYLOLOGICALLY IDENIFIED EREAKFOINTS OF INVERSIONS. I'ne breakgoints are identified using the norienclature of liesbitt and Francke (1973).

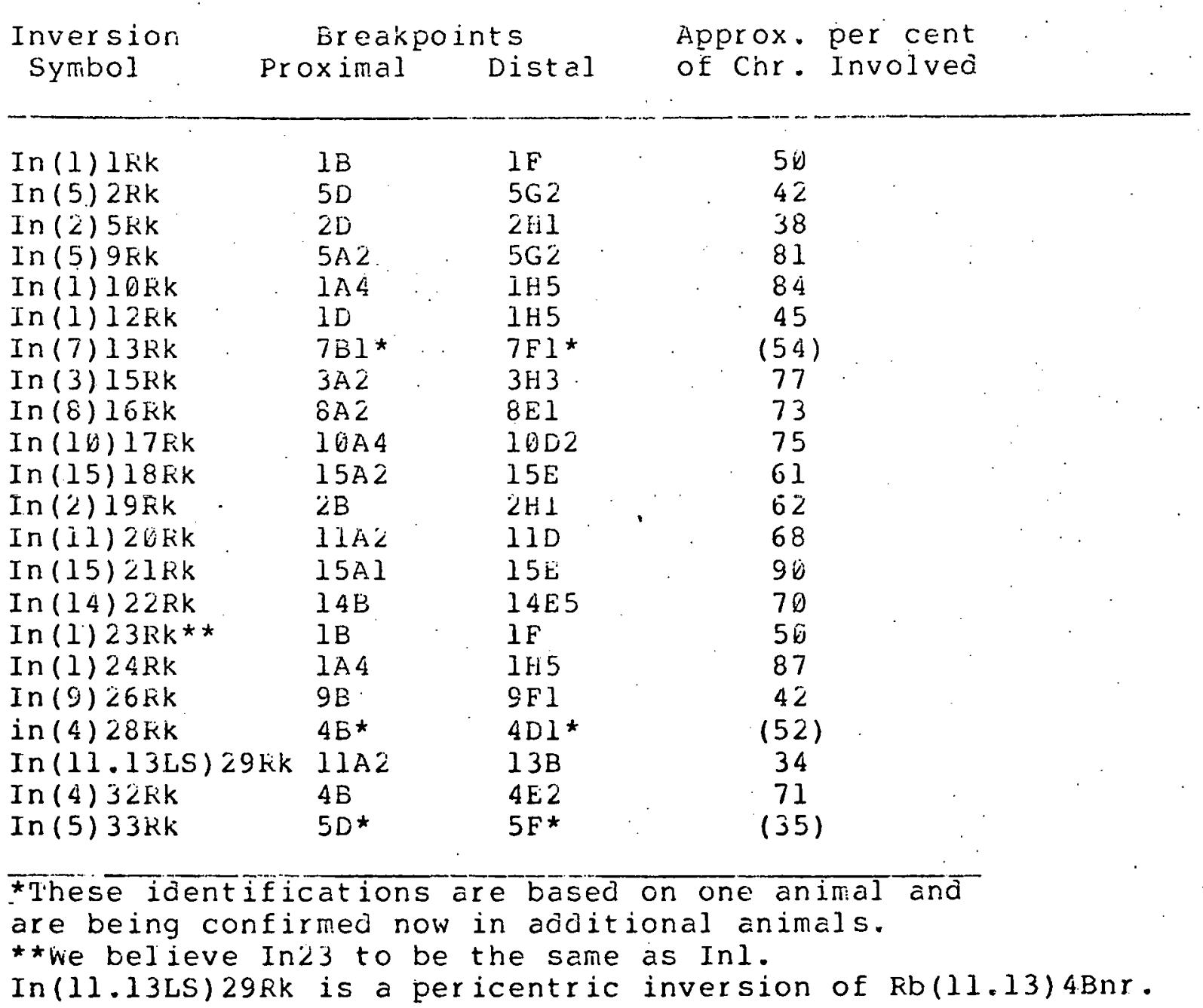



MATNTAINED. IN THE RODERICh-LAVISSON COLONY. The breakpoints are iơentified using the nomenclature of Nesbitt and Francke (1973).

Translocation Symbol

Breakpoints

$\mathrm{T}(1 ; 13) 2 \mathrm{Kk}$

$\mathrm{I}(5 ; 8) 3 \mathrm{RK}$

$\begin{array}{ll}1 \mathrm{~B}: & 13 \mathrm{~B} \\ 5 \mathrm{~F} & 8 \mathrm{C} 3 \\ 12 \mathrm{~B} & 17 \mathrm{E} 4 \\ 3 \mathrm{D} \text { or } & 4 \mathrm{C} 2 \text { or } \\ 3 \mathrm{Fl} & 4 \mathrm{C} 4 \\ 1 \mathrm{AA} 4 & 14 \mathrm{E} 5\end{array}$

$\mathrm{T}(12 ; 17) 4 \mathrm{kK}$

$\mathrm{T}(3 ; 4) 5 \mathrm{Kk}$

T' $(10 ; 14) 8 \mathrm{aRk}$

1 LिA 4

$14 \mathrm{E} 5$

* Clarification awaits.high resolution banding. In standard preparations bands $3 \mathrm{E}$ and $4 \mathrm{C} 3$ are indistinguishable from one anulher. 
were selected for testing. These came from five different geographic populations in southwestern Ontario and were homozygous for alleles at the marker loci $\mathrm{Hbb}, \mathrm{Gpi}-1$, and Idh-1. The latter gene is an isozyme marker for Chr $\mathrm{I}$ in

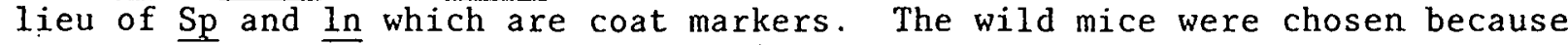
they were homozygous for alleles NOT present in the inversion stock. Of the twenty mice, two females and 10 males gave progeny when mated to the tester inversion stock. The $F_{1} s$ were backcrossed to the inversion mice and the resulting offspring were mated to provide generation IV. In only four of the 12 pedigrees have a sufficient number of offspring been produced to permit definite conclusions about the presence of lethals in these wild populations. So far in the 4th generation, the presence of genotypes is about as expected except for a numerical deficiency of the $\mathrm{Hbb} / \mathrm{Hbb}$ class which was the genetic class of the wild mice for Chr 7 . If this deficiency is real, perhaps the "wild" chromosome carries either an allele near $\mathrm{Hbb}$ which reduces viability, or a lethal allele linked but outside the inversion on Chr 7 . Complete testing of the 12 wild mice in this initial project should be completed by the end of this year (1980).

Meiotic pairing. We have continued our collaboration with Dr. Montrose $\mathrm{J}$. Moses of Duke University studying the synaptonemal complex in inversion heterozygotes. An initial paper on this work has been completed. The conclusion in this study is that there is a striking correlation between chromosomal breakpoints (as measured by synaptonemal complex and banded chromosomes) and genetic distances (as measured by standard genetic crosses). This finding is an important generalization for mammals and dispels some of the conflicting evidence presented to date.

Characterization of induced lethals. One of the important gaps in our knowledge is the extent of burden that induced recessive lethals produce in mammalian systems. So far most of the studies on recessive lethals have concerned lethal alleles at known specific loci where previously discovered viable allelic alternatives permitted identification and naming of these loci. The lethals we have induced in validating the mutation-test system utilizing inversion In(1)IRk are known to be within the inversion or perhaps just outside it, but the precise location of the loci involved is not known. We do know these lethals do not correspond with other known loci on Chr 1. Dr. Diana M. Juriloff, a postdoctoral associate in our laboratory, has completed an initial examination of these lethals with the specific objective of determining the time of death in embryogenesis. Two additional lethals were studied. These are the lethal affects of the homozygous condition of inversions In(2)5Rk and In(12)25Rk, the only two inversions displaying homozygous lethality. So far our findings show that lethal No. 1 is effective usually at birth, lethal No. 2 at birth and possibly at preimplantation as well, lethal No. 4 at birth or preimplantation, lethal No. 6 at day 7 to 10 in embryogenesis, but also some at preimplantation, the lethal of In5 at preimplantation, and the lethal of In25 at day 7 to 10 in embryogenesis. The wide variety of effects of these lethals was not unexpected. We did not believe we could make many generalizations with this initial study. The impact of the burden of these lethals in. heterozygous condition (the dominant effect of recessive lethals) is not known but preliminary evidence suggests possible slight effects on fertility. This is an important area to study and will necessitate a proportional increase in our effort to achieve. 
Mitotic crossing-over. Mitotic or somatic cell crossing-over, if it is a significantly frequent event in mammalian cells, could be an important factor in the burden expressed by recessive detrimentals and lethals. We have turned our attention to this problem this year particularly working out the experimental procedures by which we can observe mitotic crossing-over. Our hypothesis is that individuals heterozygous for paracentric inversions should show a significantly elevated frequency of mitotic anaphase bridges if mitotic crossing-over occurs. Now we have a method whereby we can place three inversions heterozygous in single individuals. This is done by breeding our stock homozygous for In(1)IRk and In(7)13Rk with any other inversion homozygous stock. The test of this system for discerning mitotic crossing-over comes from the fact that the frequency of bridges should be proportional to both the length of all. inversions combined. Initially with the collaboration of a summer student, Elizabeth Cravey, we examined liver cells of 15-day triple inversion heterozygous embryos. Due to the high rate of hematopoietic activity in the 15-day embryonic liver, the dividing nuclei could not be seen. We have now turned our attention to regenerating liver tissue in triple-inversion heterozygous adults. The method should enable us to make a statement on the frequency of mitotic crossing-over within the next year of this study.

Publications under this contract, 1980

DAVISSON, M. T., P. A. POORMAN, T. H. RODERICK, and M. J. MOSES. 198_. A pericentric inversion in the mouse. Completed for submission to Chromosoma.

JURILOFF, D. M. 198_. Differences in frequency of cleft lip among the A strain of mice. Teratōlogy (submitted).

JURILOFF, D. M., K. K. SULIK, and T. H. RODERICK. 1980. Morphogenesis of spontaneously occurring otocephaly in a newly developed mouse mutant (lethal No. 1). Teratology $21: 47 \mathrm{~A}-48 \mathrm{~A}$ (abstract).

POORMAN, P. A., M. J. MOSES, M. T. DAVISSON, and T. H. RODERICK. 198_. Synaptonemal complex analysis of mouse chromosomal rearrangements. III. Cytogenetic observations on two paracentric inversions. Completed for submission to Cytogenet. Cell Genet.

RODERICK, T. H. 1980. Inversion map of the mouse. In M. C. Green (ed.), Genetic Variants and Strains of the Laboratory Mouse. Gustav Fischer Verlag, Stuttgart (in press). 